\title{
The Settlement Morphology along The Musi River
}

\author{
Maya Fitri Oktarini ${ }^{1}$ \\ ${ }^{1}$ Department of Architecture, Universitas Sriwijaya, Indonesia \\ mayafitrioktarini@gmail.com
}

\begin{abstract}
The study examines the morphology of the settements along the Musi riverbank and focuses on the association between the settlements morphology and the characteristic of the river. Musi River consists of three river zones, i.e. upstream, middle, and downstream. The specific morphology that was studied is the distance of the buffer area, the building orientation, and the housing typology that were compared to the physical characteristics of the river and the socio-cultural of the communities. The study data was collected through satellite map and field survey on three settlement sites for each zone, including maps, sketches, photographs, and interviews. The results show the main factors influencing the settlement morphology is the community's dependent on the river. The function of the river for daily life activities influences the distance and the orientation of the settlements. The more the functions of the river for the daily life, the closer and the more oriented their settlements are to the river. Therefore, the river disasters, such as flood and erosion should keep the settlement away from the riverbank. However, the dependence on the river creates the adaptation to on building the settlements that adapt to the natural cycle. It also establishes the morphology of the settlements on the riverbank.
\end{abstract}

(C) 2018 IJBESR. All rights reserved.

Keywords: Morphology, Settlement, and Musi River

\section{Introduction}

Almost all cities in the world are developed along rivers bank or coastline. The history of urbanism has always been developed close to the water environment, although currently most of the urban development has been land-oriented due to the changes in the transportation way. Settlements along the river get benefit from the river's ecosystem service as an infrastructure for sanitation, drinking water needs, or transportation routes. In contrast to its function, river is also a source of flood or erosion disasters. The contradiction of the opposition creates the dynamics of the settlements morphology [1].

The study is focused on the distance between building and the riverbanks, the building orientation, and the typology of the residential building. The results show that the physical characteristics of the river influence the settlement morphology. The function of the river for the people daily life also affected the settlements morphology.

In the community of life whose daily life depends on the river, water circulation patterns will influence the traditions of daily life and the form of settlements [2]. The people who live on riverbanks shape the water-based communities that show cultural manifestations of water interests [3]. The importance of river ecosystem services leads to improvements in the environment and socio-economic conditions. It creates positives reciprocal between humans and the river ecosystems [4].

There are several dissertations on similar study, one of which is 'city's transformation 
along the Barito River'. It discusses the distance of settlements from the riverbank and the effects on the settlements morphology [5]. Other dissertation discusses settlement morphology on the Musi riverbank in Palembang in becoming the identity of the waterfront city [6]. The study on Lake Tempe discusses the dynamics of location, spatial, and adaptation process in inhabiting floating house [7]. Another study discusses the chronology of the river bank settlement in Bangkok through recordings and documents [8].

\section{Research Methods}

The study is focused on the relation between the settlement morphology and the existence of the river. It compared the physical characteristics of the settlements with the socio-cultural of the communities and the river characteristics. The data was collected through satellite map and survey which included maps, sketches, photographs of the settlement and the surroundings, and interviews with local residents.

The observation sites were located on the settlements along the banks of the Musi River, three settlement sites for each zone. Every site historically evolved around the river banks. The distance from the river banks and among sites, and the density of settlements are the criteria in the site selection.

Observation observes the characteristics of river banks in the settlement. Observations related to bank conditions, flow velocity, river width, water clarity. In addition to observing the physical condition of the house that stands along the banks of the river, observations also observe the daily activities of settlers related to the river.

In addition to observation, surveys were conducted with interviews with local residents. Interviews use open questions with topics that are limited to daily activities related to the river and the conditions of their homes and settlements. The interview also asked about the kind of river disaster and impact, also the community response. Respondents are owners of houses whose houses stand on the banks of the river.

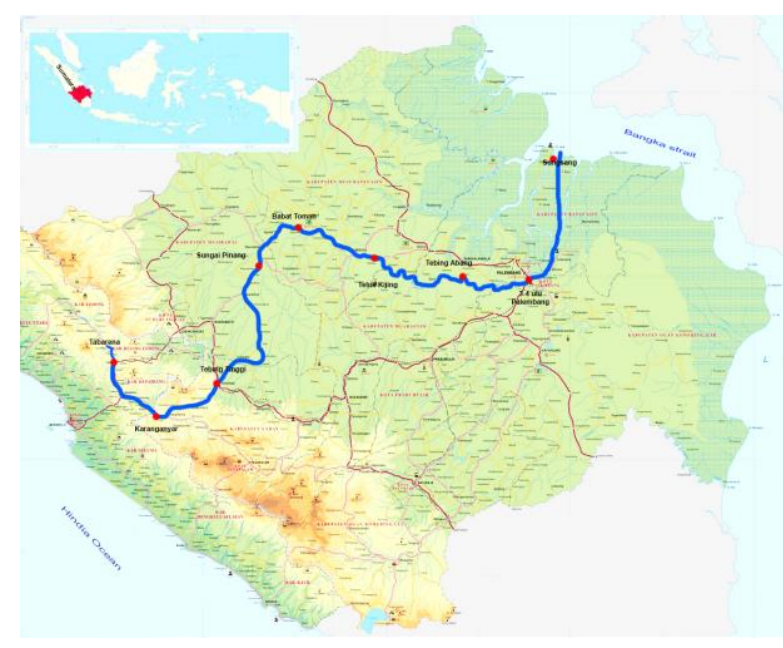

Figure 1: Map of Musi river and the study locations (Redrawn by https://www.google.com/maps)

\section{The Physical Character of Musi River}

The ecosystem of southern Sumatra is much influenced by rivers. Cities commonly evolved at the intersection of several rivers. The study obtained data of several settlements along the Musi riverbank. As the longest river in Sumatra, one of the largest islands in Indonesia, Musi River flows from the mountains in the western part of the island as the first water spring of the river which flows toward the estuary that reaches the ocean in the eastern part of Sumatra island (see Figure 1). Based on its physical characteristics, the river can be divided into three zones, i.e. upstream, middle, and downstream [9].

The upstream zone of Musi begins in Taberena, the highlands village on the hills with an elevation of $\pm 700 \mathrm{~m}$ above sea level and is surrounded by the conservation forest. The zone is earthquakes prone, has a length of $\pm 187 \mathrm{~km}$ and flows through plantation 
fields, agriculture areas, settlements, and ends at Muara Kelingi. The upstream river has clear water with a depth between 30 and $80 \mathrm{~cm}$. The discharged water highly depends on rainfall with relatively small influence from water tidal. The land topography constructs steep straight river and with water velocity of about $1.0-1.2 \mathrm{~m} / \mathrm{sec}$ it produces rafting conditions with rock bed and erosion along the river edges. The stream is often interrupted by extreme gap of land elevation that creates the waterfall. The characteristic is less suitable for an aquatic biota; accordingly, upstream people do not rely on fisheries but on agricultural and plantations. The volcanic soil with a cool climate is ideal for agricultures products, such as coffee, tea, wood, resin, and rattan. The upstream river cannot be used as water transportation; therefore, in the past, the community used boats to descend the mountain through Bukit Barisan to the stream in the foothill toward the Residency of Palembang [10].

The middle zone of Musi river ranges from Muara Kelingi to Tebing Abang with a length of about $177 \mathrm{~km}$ and an elevation between $15 \mathrm{~m}$ to $40 \mathrm{~m}$ above the sea level. It is in lowland on the mountain foot where several streams join the Musi River at medium velocity which reduces erosion. The river bed is filled with sediment and the river edge still has a firm boundary between water and land surface. The topography is relatively flat with many water traps creating swamps, so that the river condition is much influenced by the swamp around. The sloping topography flow the stream at medium speed creating a meander with a wide river. The deep and wide river with a slow velocity and warm temperatures is an ideal habitat for an aquatic life. The river in the middle zone also functions as water transportation.

The downstream zone that flows from Tebing Abang to Bangka estuary in Sungsang, is part of the river that reaches the sea. Its length is about $146 \mathrm{~km}$ and it is very flat with an elevation between 15 to $0 \mathrm{~m}$ above sea level and it has several junctions. During the rainy season, the river inundates the surrounding swamps and delta wetlands. The river velocity is very slow because of the almost flat topography and the backflow of the tides from Bangka strait. The river deposits sediment along the stream such as mud, sand, and clay. It is the river network that integrates trade routes from various agriculture and plantation areas so that it is a strategic place for trading and for people to work as traders [11].

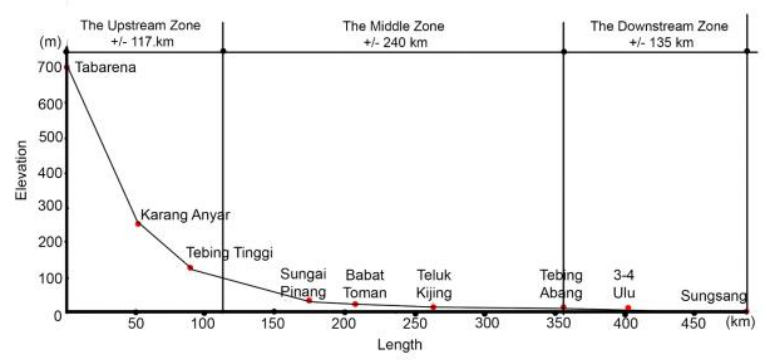

Figure 2: Horizontal profile of Musi River from upstream to downstream

\section{The Settlement's Morphology on Musi Riverbank}

There are nine locations for three Musi zones. The observation results show the site morphology of the settlements (see Figure 3) and the schematic cross-section of the settlements on the river bank (see Figure 4).

\section{The Settlement Morphology in the Upstream Zone}

The three sites in the downstream zone are Tabarena, Karang Anyar, and Tebing Tinggi. Tabarena is a village located at an altitude of $700 \mathrm{~m}$ above sea level. With a width of about $35-45 \mathrm{~m}$, the river flows from Tabarena down the forest hills to the next site at Karang Anyar, $\pm 54 \mathrm{~km}$ from Tabarena, at an altitude of $220 \mathrm{~m}$. The large gap in the altitudes flows the stream rapidly that brings out small sediments and leaves 
rocks on the river beds. From Karang Anyar, the river flows through the plain area between two foothills. Then, the stream splits and bends towards the third site at Tebing Tinggi, located $\pm 30 \mathrm{~km}$ from Karang Anyar at an altitude of $125 \mathrm{~m}$. The stream velocity is slower than the two previous sites.

People do not depend much on the river for household needs, instead they obtain household water from water springs, although they dried up in some seasons. Therefore, in the dry season, the river becomes the main source of clean water. Since it is a shallow and narrow river, it is not suitable for water transportation. Meanwhile, at Tebing Tinggi, fishery becomes a seasonal income in the rainy season as the river discharge increases. The river is wide enough for water transportation but, it is often disturbed by siltation. Therefore, usually boats are only used to cross the river instead of reaching distant places.

The observation shows the different typology of houses on each site. In Tabarena, the settlement arrangement is much influenced by topography. People search for relatively flat land $t$ composed of an organic pattern to build houses. The house's site is kept away from the river edge to avoid erosion and inundation. When the rain comes, the river flow could increase suddenly and cause overflows that inundated the surrounding. However, it was fast absorbed, so there is no flooding in the settlements. People preferred houses closer to the river branch with slower velocity. The constructions and structures of the houses are more influenced by anticipation of an earthquake. The houses were built on a stone foundation with lightweight materials and non-rigid structures. In Karang Anyar, the river velocity and the earthquake threat have declined. The houses were built closer to the river and built on stilts foundations to anticipate the surface flows and frequent flooding. Although the settlement was not directly oriented to the river, the layouts are set to arrange parallel to the river. In Tebing Tinggi, some houses are oriented toward the river. The layout of the site was a combination of the line of the topography and the river edge. In addition to stilts houses, there was another new typology house. In contrast to the traditional houses, the new shop houses were built only 5-10 m from the river edge. It was reinforced with concrete structures to avoid erosion.
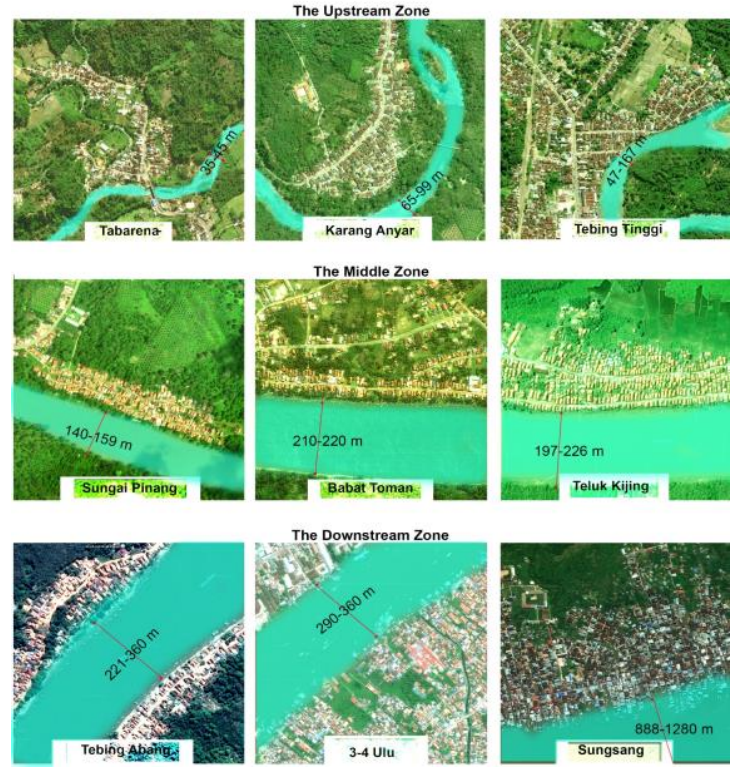

Figure 3. The morphology of settlements on the riverbank source: $\underline{w w w . v i a m i c h e l i n . c o m}$

\section{The Settlement Morphology in the Middle Zone}

The three sites in the middle zone are Sungai Pinang, Babat Toman, and Teluk Kijing. The distance between Tebing Tinggi and Sungai Pinang, located at an altitude of $36 \mathrm{~m}$, is \pm $80 \mathrm{~km}$ and the distance between Babat Toman and Teluk Kijing is $62 \mathrm{~km}$. The highest gap in the elevation of the three middle sites is only about $23 \mathrm{~m}$.

In middle zone, people utilize water from the river as source of fishery, wetland 
agriculture, water transportation, and household. Agriculture and fishery are the main sources of people livelihoods. They do the farming by relying on water source from the river overflows and rainfall. Babat Toman and Teluk Kijing are two villages famous as fish producers in South Sumatra, either in waterway or in an aquaculture. The people in Babat Toman more relies on fisheries from the waterway by trapping the fish on the swift stream, while people in Teluk Kijing more rely on the aquaculture.

River transportation begins in Muara Kelingi, the city before Sungai Pinang. From Muara Kelingi, trade boats carrying goods connecting the settlements and plantations along Musi. Along the route, there are raft houses used as warehouses for agricultural and fisheries product. In addition to the warehouses, there were also lined up raft latrines for washing, bathing, and latrine on the river. Although there was a clean water supply from public infrastructure, people still do the activities in the river.

The houses were built along the riverbank oriented toward the river. The houses have two faces; the back elevation faces the river and the front elevation to the road. Closer to the downstream zone, the settlements are developed closer to the river edge. If there is still a buffer area in Sungai Pinang, there is no buffer area between the houses and river in Teluk Kijing. The houses built directly oriented to the river edge.

The houses were built as stilt buildings to anticipate flood because of the river overflow or the tides. Initially, people did not perceive flood as a disaster. The flood brought an abundant fish and shrimp drifted by heavy streams. The river overflows also create a fertile land for farming. Unfortunately, the fertile land has decreased due to environmental damage because of plantation and mining. The development of land transportation also reduces people's dependence on the river since it is more economical and efficient. The houses were then modified to fit activities to the land transportation. People modified the house on the empty space under the house in the stilt foundations as room of the house. As a result, the houses were no longer adaptive to flood conditions. It changes people perception of the floods from a blessing into a disaster.

\section{The Settlement Morphology in the Downstream Zone}

The downstream zone begins in Tanah Abang at an elevation of $7 \mathrm{~m}$ and ends at Sungsang Village that almost parallel to sea level. It is the meeting point of the streams. The river in the downstream zone is very wide even sometimes with an unclear boundary between land and water. The river edge is a slope with slow velocity so that erosion is rare. The settlements are usually developed at the junctions of several rivers. The more river junctions, the faster the growth of the settlements will be. Tanah Abang is located at the junction of Musi river with its branch, Palembang is located at the junction of three major rivers with Musi river, while Sungsang is located at the estuary of Musi dan Telang rivers. The junction of three rivers (Komering, Keramasan, and Ogan) triggered Palembang to be the capital of South Sumatra since these rivers connected to most areas in southern Sumatra.

In the downstream zone people livelihoods used to depend much on the river. It was the source of water for daily needs, fishery and trade transportation. The settlements were built along the wetland on the river bank directly connected to the river transportation. The riverfront houses had two faces with the main face is directed to the river. Each riverfront house had a terrace with boat dock. The houses stood on the wetland that was always inundated, therefore, it was built 
on a stilt or rafts foundation. Later, people were no longer dependent on the river as used to be. The raft house was changed the function only for a stall for selling fuels or others boat needs.

The layout of the site shows that the nearest road from the river edge is separated by dozens of houses and is up to hundreds of meters away. Some houses are clustered into small villages equipped with plazas that became the center of the land orientation. The circulation paths are connected between houses by long bridges standing on rows of stilts. Although at Tanah Abang, the settlement morphology lined along the river bank resembling the middle zone morphology, it shows the increasing number of row houses at some site parts. The downstream morphology has fully configured at 3-4 ulu in Palembang. Moreover, at Sungsang, where most of the population are fishermen, the settlement has been integrated into the river. There was only one road to the village and there is a dock along the river edge which indicates the importance of the river way in Sungsang.
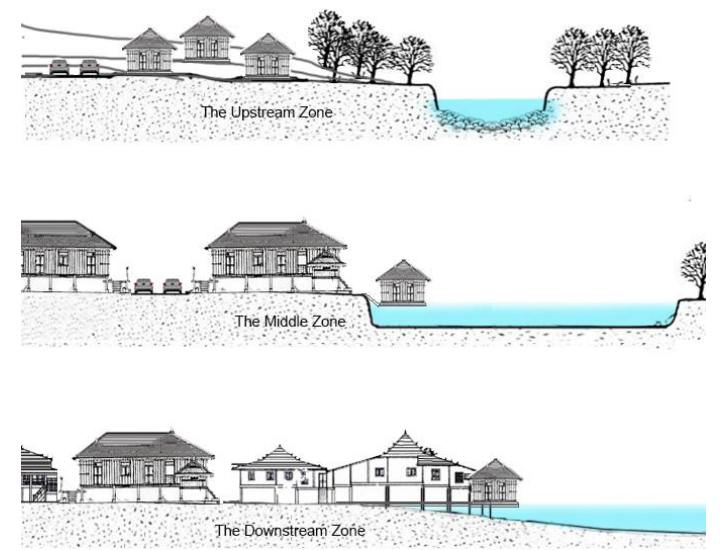

Figure 4: The schematic sections of the settlements and the river

\section{Summary and Discussion of Results}

The results show that there are differences in the settlement morphology of the three Musi zones found on the width of buffer area, the orientation, and the building typology. The morphology of the settlements is more generated by the river function for the people livelihoods than the treatment of the river disaster. The main factor that influences the settlement morphology is people's dependence on the river function. The river is a source of clean water, fertile land, fishery, and transportation route. (see Table 1). The natural disaster, such as flood and erosion, should keep the settlement away. However, People build the settlement that adapt to the disaster. The people adaptation to river because of depend on the functions or deal with river disaster establish the morphology of the river bank settlements.

In the upper zone, which is a source of springs, settlements are built far from the banks of the river. Residents do not depend much on the river. Settlements and rivers are separated by fertile trees which indirectly preserve rivers from sedimentation and pollution of the household. It also reduces the effects of river disasters into settlements, such as erosion, flooding, or drifting. Unlike the middle zone, settlements are built right on the banks of the river. Although the threat of erosion decreases, the possibility of flooding increases. It is because residents need proximity to the river as a source of livelihood and daily needs. Moreover, in the downstream zone settlements are built directly above the tidal riverbank area. There is no strict boundary between settlements and rivers. In this zone, residents adapt to the river ecosystem because it is very influential for their livelihoods and daily needs. The width of the buffer area is in accordance with the purpose of protecting the river ecosystem, which is more than 30 $\mathrm{m}$ in the area of conservation of wild habitat ecosystems, and about $30 \mathrm{~m}$ for rural areas, or less than $30 \mathrm{~m}$ in urban areas [12]. 
Table 1: The different of the settlement morphology in three zones

\begin{tabular}{|c|c|c|c|}
\hline & \multicolumn{3}{|c|}{ River Zone } \\
\hline & Upstream & Middle & $\begin{array}{l}\text { Downstre } \\
\text { am }\end{array}$ \\
\hline $\begin{array}{l}\text { Dependence } \\
\text { to the river }\end{array}$ & $\begin{array}{l}\text { Daily water } \\
\text { in dry } \\
\text { season }\end{array}$ & $\begin{array}{l}\text { Daily water, } \\
\text { River Bathing } \\
\text { and Washing, } \\
\text { Transportation } \\
\text { way, } \\
\text { Wetland } \\
\text { Agriculture, } \\
\text { Fishery }\end{array}$ & $\begin{array}{l}\text { Trade } \\
\text { transportati } \\
\text { on route, } \\
\text { Daily } \\
\text { water, } \\
\text { River } \\
\text { Bathing } \\
\text { and } \\
\text { Washing, } \\
\text { Fishery }\end{array}$ \\
\hline $\begin{array}{l}\text { Width of } \\
\text { Buffer Area }\end{array}$ & $>30 \mathrm{~m}$ & $0-5 \mathrm{~m}$ & - \\
\hline $\begin{array}{l}\text { Building } \\
\text { Orientation }\end{array}$ & $\begin{array}{l}\text { Road or } \\
\text { Land } \\
\text { Topography }\end{array}$ & $\begin{array}{l}\text { Land (main) } \\
\text { and River }\end{array}$ & $\begin{array}{l}\text { River } \\
\text { (main) and } \\
\text { Plaza on } \\
\text { land }\end{array}$ \\
\hline $\begin{array}{l}\text { House } \\
\text { Typology } \\
\text { from } \\
\text { Adaptation } \\
\text { of Disasters }\end{array}$ & $\begin{array}{l}\text { Earthquake } \\
\text { resistant } \\
\text { Houses that } \\
\text { built away } \\
\text { from the } \\
\text { river erosion } \\
\text { and river } \\
\text { flooding }\end{array}$ & $\begin{array}{l}\text { Stilts and } \\
\text { rafts houses } \\
\text { to adapt } \\
\text { erosion and } \\
\text { river flooding }\end{array}$ & $\begin{array}{l}\text { Stilts and } \\
\text { rafts } \\
\text { houses to } \\
\text { adapt } \\
\text { erosion } \\
\text { and river } \\
\text { flooding }\end{array}$ \\
\hline
\end{tabular}

The dependence on river function not only determines the distance of the buffer area, but also the orientation of the buildings. The settlement orientation changes gradually from the upstream to the middle until the downstream. The settlements in the upstream zone are not oriented to the river. The layout of the building is adjusted to topography and circulation path of the land. In the middle zone, every riverfront house has two faces with the main direction is to the land. While in the downstream zone, the riverfront house has two faces with the main orientation to the river.

People's dependence on rivers influence their adaptation manifested in the typology of the building. In the upstream where river functions have little effect on people's lives; people avoid the erosion by keeping away the settlement from the river banks. The construction of the houses was addressed to encounter an earthquake. Despite the threat of flood, in the middle zone people built the houses on the riverbank. People constructed the stilt house to avoid the surface flows and the river overflows. In the downstream zone, people built the houses that suit tidal wetland conditions. In addition to the stilt house, another house typology is the raft house that commonly encountered on a wide river with a slow velocity stream.

The rivers have an influence on the formation of the settlement morphology. The settlement morphology in the upstream is oriented toward land-based settlement. It separates land for a built area and river for a natural area. The people avoid building on river banks and flood. In the downstream zone, the settlements are located on the wetland of riverbanks, a transition area where no clear boundary between land and river and adapt to daily tidal and flood [13].

\section{References}

[1] Shannon, Kelly. Eco-Engineering for Water: From Soft to Hard and Back. In Resilience in Ecology and Urban Design, S.T.A. Pickett, M.L. Cadenasso, and Brian McGrath, eds. Future City. Dordrecht: Springer Netherlands; 2013, p. 163-182.

[2] Yodsurang, Patiphol, Miki Hiromi, and Uekita Yasufumi. A Traditional Community in the Chao Phraya River Basin: Classification and Characteristics of a Waterfront Community Complex. Asian Culture and History; 2015, 8(1): 57.

[3] Papayannis, Thymio, Dave Pritchard, and Mediterranean Institute for Nature and Anthropos. Culture and Wetlands in the Mediterranean: An Evolving Story. Athens: Med-INA; 2011.

[4] Groffman, Peter M., Daniel J. Bain, Lawrence E. Band, et al. Down by the Riverside: Urban Riparian Ecology. Front Ecol Environ; 2003, 1(6): 315-321.

[5] Mentayani, Ira. Transformasi Adaptif Permukiman Tepi Sungai di Kota Banjarmasin Kasus: Barito-Muara Kuin, Martapura, dan Alalak, Universitas Gadja Mada; 2015.

[6] Anwar, Widya Fransiska. Identification of the Morphological Characteristic of Palembang Riverside Settlement. Universiti Teknologi Malaysia; 2013.

[7] Naing, Naidah, and Haryanto Halim. Sistem Struktur Rumah Mengapung di Danau Tempe 
Sulawesi Selatan Structure System of Floating House at Tempe Lake in South Sulawesi. Jurnal Permukiman; 2013; 8(3), p.143-152.

[8] Denpaiboon, Chaweewan. Transformation by Modernization of the Traditional Waterfront Settlements in the Context of Their Coexistence with Aquatic Environment: A Case Study of Raft House and Pillar House in Thailand. Kyoto University; 2001.

[9] Samuel; Susilo Adjie. Zonasi, Karakteristik Fisika-Kimia Air dan Jenis-Jenis Ikan yang Tertangkap di Sungai Musi, Sumatera Selatan (Zonation, Physio-chemical Characteristic of Water and Fish species of Musi River). Jurnal Ilmu-Ilmu Perairan dan Perikanan Indonesia; 2008; 15(1), p.4148.

[10] Santun, Dedi Irwanto Muhammad, Murni, and Supriyanto. Ilirin Dan Uluan: Dinamika Dan Dikotomi Sejarah Kultural Palembang. Yogyakarta: Eja Publisher; 2010.

[11] Nurhan, Kenedi. (2010). Jelajah Musi: Eksotika Sungai di Ujung Senja. Jakarta: PT. Gramedia. 2018.

Pinke, Zsolt, László Ferenczi, Gyula Gábris, and Balázs Nagy. Settlement Patterns as Indicators of Water Level Rising? Case Study on the Wetlands of the Great Hungarian Plain. Quaternary International; 2016; 415, p. 204-215.

[12] Hawes, Ellen, and Markelle Smith. Riparian Buffer Zones: Functions and Recommended Widths. Eightmile River Wild and Scenic Study Committee; $2005 ; 15$.

[13] Thaitakoo, Danai, and Brian McGrath. Changing Landscape, Changing Climate: Bangkok and the Chao Phraya River Delta. Places; 2008; 20(1), p.3035 . 